Daniel N. Warshawsky*

\title{
The Perpetual Uncertainty of Civil Society: Case Study of an Anti-Hunger Organization in South Africa
}

\begin{abstract}
South Africa has one of the most active civil societies in the world, with more than 85,000 registered civil society organizations (CSOs). However, the growth of CSOs in post-apartheid South Africa does not necessarily imply that the sector is strong. While it is true that the demise of the apartheid regime increased democratic representation within South Africa, CSOs have experienced a series of institutional challenges which have weakened their organizational stability. This has included increased oversight by the state, inefficient and inconsistent funding from government, fickle demands by private donors, and competition from other sectors. Through an in-depth case study of a historically prominent CSO in South Africa, this paper critically analyzes the institutional challenges faced by CSOs in South Africa. Data findings suggest that lack of long-term funding support, ineffective state funding mechanisms, and competition from state programs and new CSOs have resulted in perpetual uncertainty for some CSOs. In all, these institutional problems may have the potential to shrink, destabilize, and limit the viability of South African CSOs. Moreover, this suggests that South African democratization may have simultaneously produced new opportunities for some CSOs, yet reinforced unequal power relations for other CSOs and thus produced a highly polarized CSO landscape.
\end{abstract}

Keywords: civil society, non-governmental organization, nonprofit, South Africa, food insecurity, hunger

DOI 10.1515/npf-2013-0006

*Corresponding author: Daniel N. Warshawsky, Spatial Sciences Institute, University of Southern California, 3616 Trousdale Parkway Hancock Foundation B55B, Los Angeles, CA 90089, USA, E-mail: warshaws@usc.edu 


\section{Introduction}

As noted by key studies, civil society organizations ${ }^{1}$ (CSOs) have increased across the world (Lewis 2001; Salamon 2010). Similarly, the growth of CSOs in South Africa has been rapid with over 85,000 registered CSOs (Department of Social Development 2012b). South African CSOs contribute $\$ 1.7$ billion annually to the economy, accounting for $1.3 \%$ of the country's GDP (Swilling, Russell, and Habib 2002). Although South African civil society is small when compared to North America and Western Europe, ${ }^{2}$ South African civil society is the largest in Africa and second largest in the Global South (Salamon, Sokolowski, and List 2004).

However, the growth of CSOs has not ensured that the sector is strong, as South African CSOs remain significantly polarized by race and income (Warshawsky 2013, 2014). While the demise of apartheid increased democratic representation within South Africa, CSOs have been confronted with lack of financial and human resources and at times, an antagonistic central state ${ }^{3}$ (Camay and Gordon 2001; Umhlaba Development Services 2005). Although these problems are sometimes attributed to the growing pains of a young democracy, others argue that these struggles point to fundamental institutional challenges and limited impacts of CSOs in South Africa (Bond 2006; Desai 2002). These scholars contend that there is a direct relationship between the sector's size and its fragmentation and ineffectiveness, as societal inequality has both facilitated the growth of CSOs yet also limited their capacity to operate. As noted by numerous key scholars (Bratton 1989; Swilling, Russell, and Habib 2002; Young 2000, 2006), CSOs maintain important roles to both supplement state programs and ensure state accountability. Yet, although more than one billion Rand is spent each year to fund South African CSOs (Swilling et al. 2004), it is unclear whether CSOs are capable of producing expected outcomes to reduce poverty, empower neighborhoods, and democratically represent communities. While the state, private sector, and CSOs all vie to maximize their institutional autonomy in relation to each other (Bratton 1989), CSOs are arguably in the

1 African civil society is a fluid, relational, and socially constructed concept historicized in local contexts (Tostensen, Tvedten, and Vaa 2001).

2 These countries often have civil societies with 2-3 times the percentage contribution to country GDP (Salamon, Sokolowski, and List 2004).

3 The state is a product of the country's colonial and apartheid history (Terreblanche 2002). While it has devolved governance to local institutions (Rogerson 2004), state formation reflects the complexities of extreme socio-spatial segregation unique to South Africa (Pieterse et al. 2008). 
weakest position, since they rely so heavily on funding from other institutions (Swilling, Russell, and Habib 2002; Warshawsky 2014).

Through an in-depth case study of a historically prominent CSO named Operation Hunger $(\mathrm{OH})$, this paper critically analyzes the institutional challenges faced by CSOs in South Africa. To this end, two research questions drive this study. First, what is the organizational structure of $\mathrm{OH}$, and how has this contributed to its current institutional crisis? Second, what do these findings suggest about the viability of South African CSOs more broadly? To answer these research questions, this paper analyzes key institutional reports from 1980 to 2012 and in-depth interview data from 2007 to 2012. This includes interviews of administrators, managers, fieldworkers, and community stakeholders working at $\mathrm{OH}$, government departments, private donors, and partner CSOs.

Overall, data in this paper point to problematic findings. Given that $\mathrm{OH}$ has operated for over three decades, $\mathrm{OH}$ represents an outlier or best case scenario CSO in South Africa, since most CSOs never last more than a few years. However, as discussed in this paper, severe institutional challenges, ${ }^{4}$ including lack of long-term donor support for welfare-oriented projects or human capital, ineffective state funding mechanisms, and competition from state programs and new CSOs, have forced $\mathrm{OH}$ to the brink of closure.

The structure of the paper is as follows. After discussing the history of stateCSO relations in South Africa, post-apartheid CSOs in South Africa, and methods used, this paper critically analyzes $\mathrm{OH}$ as a case study. While $\mathrm{OH}$ does not reflect the entirety of CSOs in South Africa, findings point to institutional problems which may impact the sector at large.

\section{The history of state-civil society relations in South Africa}

South African CSOs reflect the diversity of African, European, and Asian peoples who have inhabited the country over the centuries. Although these groups interacted at times, racist policies and uneven financial support ensured that CSOs would be polarized, fragmented, and unstable (Greenstein, Heinrich, and Naidoo 1998). During the apartheid regime from 1948 to 1994, polarization of CSOs was especially pronounced as the apartheid state encouraged white-run CSOs and systematically suppressed non-white CSOs, especially those

4 Institutional challenges are defined as issues that weaken the financial sustainability, mission, programs, or structure of an organization (Swilling, Russell, and Habib 2002). 
associated with unions or political movements (Swilling, Russell, and Habib 2002). After the 1976 Soweto uprising, CSOs played important social service and community organizing roles as part of the anti-apartheid movement. Increased involvement of young activists and international resources empowered CSOs in the anti-apartheid struggle (Habib and Taylor 1999).

With the development of a democratic South Africa in 1994, the post-apartheid state started to incorporate and institutionalize CSOs (Habib 2005). In particular, through the passage of new policies, including the 1996 Growth, Employment, and Redistribution (GEAR), 1998 White Paper on Local Government, and 2000 Municipal Systems Act, the South African state devolved and decentralized key economic and poverty functions to local institutions (Department of Finance 1996; Department of Provincial and Local Government 2000; Republic of South Africa 1998b). These policies have promoted local economic development (LED) through a process of integrated development planning (IDP) that balances economic growth and poverty alleviation, emphasizes local control and flexibility, and includes institutions across scales and sectors (Rogerson 2004). Through the Nonprofit Organisations Act of 1997, Lotteries Act of 1997, and National Development Agency Act of 1998 (Republic of South Africa 1997a, 1997b, 1998a), the South African government formally institutionalized CSOs into society.

However, while the state decentralized state powers to break apart apartheid institutions and increase local control, these shifts have increasingly placed pressure on CSOs to reduce inequality and promote development (Bond 2000). In addition, according to recent studies (Camay and Gordon 2001; Swilling, Russell, and Habib 2002), CSOs have been forced to find new funding sources, hire skilled staff, and reinvent organizational mission, as apartheid era flows of money and people to CSOs ended once the apartheid regime imploded in 1994. Moreover, antagonism between the state and CSOs has increased, as many CSOs have become dissatisfied with the state's registration processes, funding mechanisms, and development course. In this way, both the state and CSOs have seen each other as competing powers or bureaucracies struggling over the future of South Africa (Bratton 1989; Young 2000, 2006).

Most recently from 2007 to 2012, state-CSO tensions have flared over recent registration changes and policy shifts initiated by the Department of Social Development (DSD). While the national Nonprofit Organisation (NPO) Register is always in flux due to turnover, the DSD has taken an active approach to ensure NPO compliance (Bok 2012; Department of Social Development 2012a). In early 2012, this resulted in the forced deregistration of 23,000 NPOs and flagged non-compliant status of 35,000 NPOs (Barnard 2013). According to the DSD, these 58,000 organizations failed to provide the paperwork required by law. 
However, numerous complaints regarding the nature of this deregistration process resulted in the re-registration of all organizations in February 2013 on the condition that organizations provided paperwork within six months.

Due to this deregistration crisis, the DSD is developing a new Policy Framework on Nonprofit Organisations Law to codify important changes to NPO registration and oversight procedures (Department of Social Development 2012b). This includes the creation of the South African Nonprofit Organisations Regulatory Authority (SANPORA) to register, monitor, guide, sanction, and prosecute non-compliant Organisations. While the major goals of the 1997 Nonprofit Organisations Act were to develop a supportive and enabling institutional environment, the Policy Framework on Nonprofit Organisations Law emphasizes enforcement and regulation of registered NPOs. Since this law is only a working document at this point, it is unclear how the policy will be finalized. In the meantime, many activists and legal scholars are concerned about its implications given its potentially punitive orientation (Wyngaard 2013).

\section{Conceptualizing post-apartheid civil society in South Africa}

Due to the persistence of socio-economic inequality and lack of confidence in the state to improve people's lives, CSOs have grown rapidly since 1994 (Ballard et al. 2006; Desai 2002). According to DSD, 85,039 registered NPOs exist as of June 2012 (Department of Social Development 2012b), almost double the number from 2006. As the largest in Africa and second largest in the Global South, South African CSOs are a R9.3 billion industry ( $\$ 1.7$ billion) with 645,316 workers, accounting for $8.7 \%$ of the non-agricultural workforce (Swilling, Russell, and Habib 2004). South African CSOs are funded by government (44\%), fees (32\%), and philanthropy (24\%), with most of this funding flowing to organizations focused on social services (26\%), development/housing (18\%), and culture/ recreation (18\%). Most South African CSOs are small, as $80.5 \%$ have 10 or fewer employees.

In line with Habib (2005) and Habib and Kotzé (2003), contemporary South African CSOs include non-governmental organizations (NGOs), communitybased organizations (CBOs), and social movements (SMs). First, NGOs operate programs in line with donor priorities (Warshawsky 2013, 2014). Funded by private donors and located in white, upper-middle class communities, NGOs have budgets over $\$ 50,000$ per month and at least 15 full-time staff. Due to their visibility and long institutional histories, NGOs are well-positioned to access 
corporate funding as a way to compensate for inadequate or inefficient public funding (Friedman, Hudson, and Mackay 2008). Second, CBOs operate basicneed programs (Warshawsky 2013, 2014). Funded by community members and located in black, lower-income communities, CBOs have budgets under $\$ 1,000$ per month with few if any full-time staff. Since CBOs are dependent on resources from community members, their closure rate is high. Third, SMs contest the state and capital as a way to promote social, economic, and environmental justice. For this reason, they are managed and operated by volunteers, less formalized than NGOs or CBOs, and more aggressive in their tactics (Ballard et al. 2006; Desai 2002).

\section{Methods}

To start, I analyzed OH's annual reports and institutional documents to highlight OH's budget size and composition, program types, and philosophical orientation toward programming. Next, I conducted 19 interviews ${ }^{5}$ with administrators and fieldworkers affiliated with $\mathrm{OH}$ from 2007 to $2012 .{ }^{6}$ Although open-ended, interviews identified the institutional operations, funding sources, and structure of $\mathrm{OH}$. When possible, I went to program sites to examine projects and interact with community stakeholders.

Also, 13 in-depth interviews ${ }^{7}$ were conducted with key government administrators, private sector donors, and managers of CSOs affiliated with $\mathrm{OH}$ from 2007 to $2012 .^{8}$ In these interviews, I examined the institutional collaboration and conflict between $\mathrm{OH}$ and its partner organizations. Interviews with government administrators highlighted the motivations behind food policies and state-CSO relations. In addition, interviews with private sector donors revealed impetus for supporting CSOs such as $\mathrm{OH}$, while interviews with affiliated CSOs provided insight into $\mathrm{OH}$ from a different place within the organizational delivery network.

5 In-depth interviews were conducted at institutions 9am-5pm, Monday-Friday. Although standard protocol guided interviews, question format was exploratory. Interviews were recorded and transcribed with agreement from the interviewee. All interviews were cited in the same manner (interviewee role, institution, date). As multiple interviews were completed on the same day, many interviews have the same interview date. Interviews were edited for grammatical clarity when necessary.

6 This time period allowed for analysis of OH's institutional instability across different staff tenures and years after the 2008-2009 global recession.

7 See note 5.

8 See note 6. 
Following completion of these interviews, data were transcribed, collated, and classified by interviewee type, organization, and quotation content. Then, interviews were analyzed with a methodological triangulation which positioned interviews in relation to the comments made by other people within similar roles at other institutions (Miles and Huberman 1994). In line with Mitchell (1983), Sayer (1992), and Yeung $(1997,2003)$, interview data were analyzed to generalize about the causal mechanisms and power relations reproducing perpetual institutional crisis at $\mathrm{OH}$.

\section{Operation Hunger: institutional history, mission, structure, and programs}

Since 1980, OH has been headquartered in Germiston, Gauteng, near Johannesburg (Figure 1). OH currently serves 19,193 people across South Africa's nine provinces through programs which nourish the poor and sharpen their entrepreneurial and

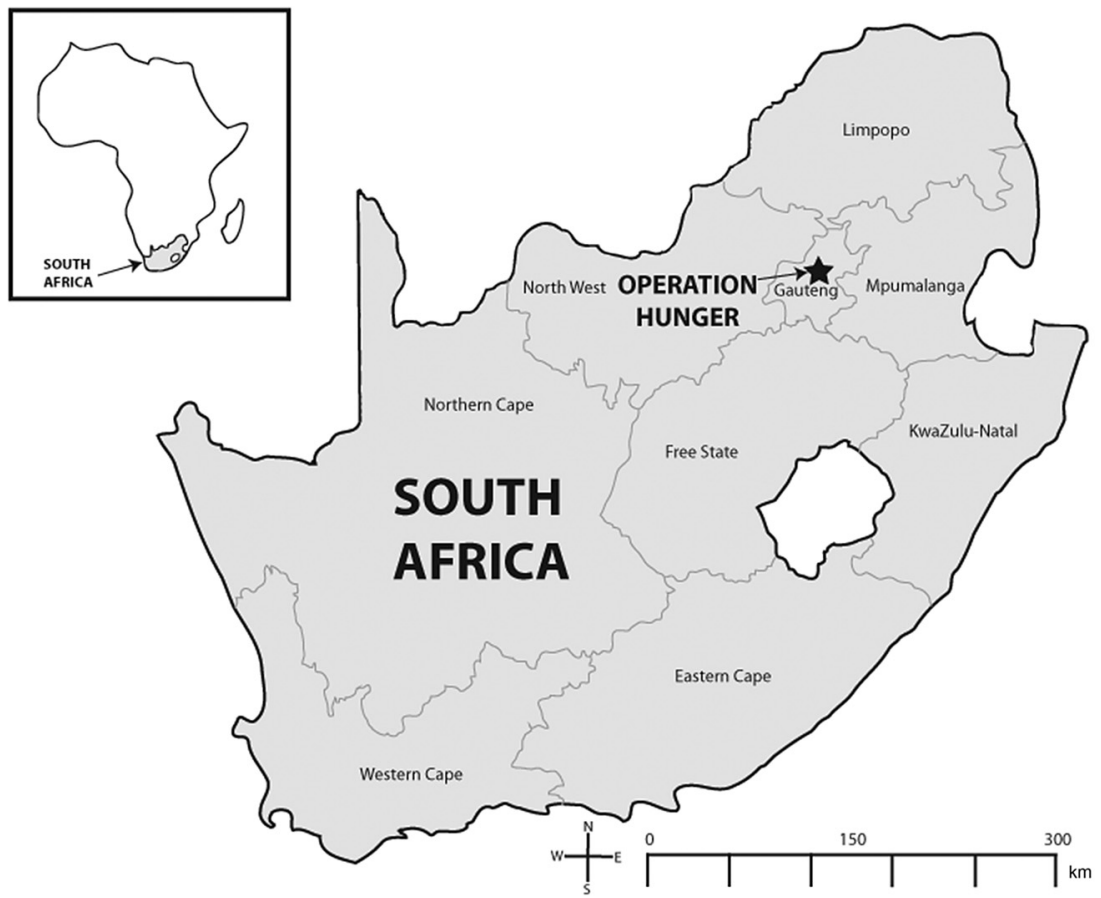

Figure 1: The headquarters location for Operation Hunger 
job skills (Operation Hunger 2013a, 2013b). Even though OH's constitution specifies that a board of trustees elects management to run the organization's daily operations, the national, regional, and community offices are led by paid staff and numerous volunteers (Operation Hunger 2013a).

While $\mathrm{OH}$ remains an anti-hunger $\mathrm{CSO}$, it changed its institutional mission in 1994 to fall under the five-part mission of development, nutrition, relief, water, and wellness (Operation Hunger 2008). However, this shift was not completely voluntary as CSOs were forced to reinvent their mission following key shifts in funding.

As (the South African) government took over (in 1994), funders from abroad (stated) that they would support the (new) democratic government and no longer channel funding to NGOs. If NGOs needed funding, they would need to contact the government. So, for many NGOs, this was their downfall, because NGOs would not get support if they were repeating a government program. Therefore, as $\mathrm{OH}$, when we saw that we were (duplicating government programs), we realized that we needed to (broaden our mission). (Administrator, Operation Hunger, August 8, 2008)

Importantly, OH's mission shift was not sufficient to prevent a substantial size reduction in OH's operating budget (Figure 2). OH's budget has shrunk from $\mathrm{R} 84,092,664^{9}$ in fiscal year ${ }^{10} 1989-1990$ to $\mathrm{R} 6,709,058^{11}$ in fiscal year 2011-2012, although the operating budget was as low as $\mathrm{R} 2,686,788^{12}$ in fiscal year 20032004. While $\mathrm{OH}$ once received substantial donations from a range of donors, these streams of money permanently stopped during the mid-1990s. In the 20112012 fiscal year, OH's operating budget was comprised of large funding from domestic food corporations such as the SPAR Group (R1,500,000 $\left.{ }^{13}\right)$ and domestic and international government agencies, such as the South African Lottery $\left(\mathrm{R} 2,800,000^{14}\right)$, Irish Aid $\left(\mathrm{R} 1,200,000^{15}\right)$, and USAID $\left(\mathrm{R} 373,000^{16}\right)$. As is discussed in the following section, funding inconsistencies are centrally related to OH's current budget crisis.

9 Figures compiled from key publications (Operation Hunger 1996, 2005, 2006, 2007, 2008, 2009, 2010, 2011, and 2012 and interviews 2007-2012). All Rand values are constant inflation adjusted values based on the 2011 exchange rate of R7.26 to $\$ 1$.

10 Fiscal year is April 1-March 31.

11 See note 9 for constant Rand value normalization.

12 Ibid.

13 Ibid.

14 Ibid.

15 Ibid.

16 Ibid. 


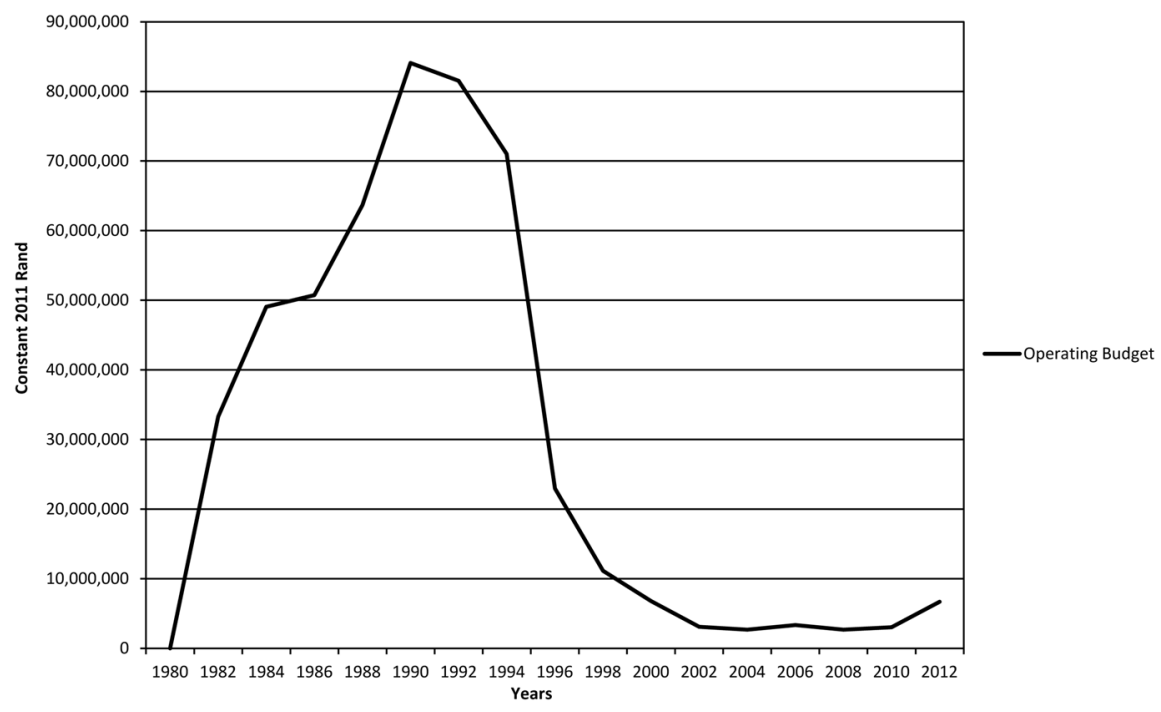

Figure 2: The 1980-2012 operating budget for Operation Hunger

\section{Operation Hunger: institutional crises}

$\mathrm{OH}$ has faced major institutional challenges during its existence. The first series of crises started in the early 1990s when high-level OH administrators misappropriated money for personal gain (Administrator, Operation Hunger, June 3, 2009). Those responsible for the misdeed were fired; however, the subsequent lack of institutional legitimacy resulted in reduced funding for years.

In 1992, there was fraud in Operation Hunger. It involved some of the senior people. They set up a mill that didn't exist that fed maize and stuff to a village. It was over a million Rand that had gone into different directions. In addition, the board at that time did not do a proper full police investigation, and so it looked like a cover up. So, a number of the donors started querying things. (Administrator, Operation Hunger, June 3, 2009)

In addition, the timing of this fraud crisis was particularly poor, as donors began channeling their money away from CSOs once apartheid ended (Administrator, Operation Hunger, August 8, 2008).

(With the end of apartheid) in 1994, many donors stopped giving to NGOs and gave to government. That hit Operation Hunger quite hard (since we were already dealing with the fraud crisis). It has taken quite a long time to get the debt written off, with lots of negotiations. (Administrator, Operation Hunger, June 3, 2009) 
Arguably, $\mathrm{OH}$ was able to successfully negotiate itself through these crises by ensuring stronger internal governance procedures and recasting its mission as a development CSO. In addition, $\mathrm{OH}$ has produced annual reports and in-depth audited financial reports yearly since the crisis to ensure organizational transparency and accountability. ${ }^{17}$ While it is unquestionable that $\mathrm{OH}$ has never reclaimed the funding it had before these crises in the 1990s, it had recovered its reputation as a legitimate organization by the late 1990s-early 2000s. ${ }^{18}$

However, by 2012, OH was facing the prospect of severe program reductions or even closure. There are a number of reasons for OH's current existential crisis. Most fundamentally, $\mathrm{OH}$ has struggled to find donors interested in funding its mission, since many donors see $\mathrm{OH}$ as a feeding organization only.

I must tell you that most donors don't give direct feeding money. What they will do; however, is that they will give money for (what they see as development projects, so) we seldom do handouts. In the old days, you had a truckload of stuff, and you just handed out food. (Administrator, Operation Hunger, March 12, 2009)

Finding donors has been a bit of a challenge. There are still very few who have an interest in funding those organizations who work on malnutrition. (Administrator, Operation Hunger, August 6, 2012)

This has been especially difficult, since donors often believe government is the purveyor of welfare programs and supplemental CSOs like $\mathrm{OH}$ which fill gaps in state services are simply redundant or competing with these services (Young 2000, 2006). ${ }^{19}$

Most donors think that (government grants) are somehow addressing households' basic needs. But, is that adequate enough for them to survive for a month? I don't think so. Our programs are coming in to bridge that gap. (Administrator, Operation Hunger, August 6, 2012)

Although $\mathrm{OH}$ attempts to rebrand itself through word-of-mouth and its annual reports, $\mathrm{OH}$ does not actually have any full-time marketing staff. This has reinforced its visibility problem and thus worsened its already existing funding problems:

One of the main challenges we are facing (as an organization) is marketing and (this is because) we don't have the funding to have an actual (marketing) person. Nobody knows

17 Although unevenly regulated, the state has required CSOs to report their financials since 1997.

18 This fact has been cross-checked with numerous CSOs.

19 The South African government spends more than R118 billion yearly on welfare (South African Treasury 2009). 
about $\mathrm{OH}$ sometimes. I mean some people say “OH are you still there?” (Administrator, Operation Hunger, August 6, 2012)

Even when donors support OH's projects, donors typically loathe to fund administration costs. This has resulted in poorly trained fieldworkers and community members, and eventually projects suffer:

One of the challenges at $\mathrm{OH}$ is limited training, because of the lack of funds. Our (projects) work, because we train participants on the ground. Donors often don't want to cover administrative costs and salaries. (Administrator, Operation Hunger, August 6, 2012)

While the challenge to cover administrative costs is common across the sector as many donors view it as an inefficiency or waste of money (Bebbington, Hickey, and Mitlin 2008), it is especially punishing for CSO such as $\mathrm{OH}$ which are already on the brink of closure. ${ }^{20}$

Equally problematic, private funders often want to see the outcomes immediately with measurable results, even though projects are often tied to multiple issues or take years to produce results.

Many (donors) give us funding to tackle only one aspect of the problem in the community. (However), you cannot measure whether you have had an impact in that community without (long-term funding). They also want to see that you have brought about changes in that community. When they cannot see any change, they do not really want to continue funding. (Administrator, Operation Hunger, August 8, 2008)

To offset funding shortfalls and partial service coverage, $\mathrm{OH}$ has partnered with other food-oriented CSOs. However, this has also resulted in partner CSOs' failures becoming OH's problems.

We used to get so much (food from our partner NGOs). We had to take more than one vehicle and it was huge, massive amounts. And, slowly, it started to dwindle and then it went down completely. (Administrator, Operation Hunger, August 6, 2012)

In addition, donors, especially government, are supportive of the fast growing numbers of NPOs at the expense of $\mathrm{OH}$ :

The mushrooming of NGOs (is a key problem for us, since funders) have to spread their resources across and also reduce allocation to those that have been with them for a longer period. Unfortunately, for the older NGOs, the focus of donors and

20 OH's 10\% administrative costs are average compared to similar organizations (Camay and Gordon 2001). 
government (is to fund these new organizations). (Administrator, Operation Hunger, August 6, 2012)

To maximize its chances at success, $\mathrm{OH}$ has tried to "sell" its project ideas to government to ensure that the relevant South African departments visualize their programming and know OH's management team.

The only ways we could make a mark with government is (to show) what we can do. When they see the result of our intervention, (they realize that) NGOs can also make a mark in terms of community development. There is this mentality in government that government (is the one) that can actually address problems. (For this reason), NGOs are ignored. (Administrator, Operation Hunger, August 6, 2012)

These comments reinforce the idea that supplemental CSOs which fill gaps in state services are redundant and ripe for cooptation or dissolution (Bratton 1989; Young 2000, 2006). As noted by Desai, Maharaj, and Bond (2011) and Bratton (1989), the degrading of CSOs is key to reinforcing the state's legitimacy as the key service provider.

In addition, lack of follow through on government funding is a perpetual problem.

We had money promised to us through the (government funding agency called the) NDA. We still have funds outstanding from them. We even had a contract signed and everything. (Administrator, Operation Hunger, August 8, 2008)

(The government) has not called for applications now (for two years). We keep checking and they haven't called (for applications), but they won't say why and you cannot get an answer from them. (Administrator, Operation Hunger, August 6, 2012)

This is quite concerning as it challenges the notion that there is a place for complementary CSOs which can actually successfully work with and be funded by government (Young 2000, 2006). Moreover, it remains unclear to what extent the South African state views CSOs as being anything other than adversarial (Bond 2006).

The lack of government funding would not be a death blow to $\mathrm{OH}$; however, $\mathrm{OH}$ has been unable to secure funding from any sector. Private donors support $\mathrm{OH}$ in smaller amounts than ever before in their institutional history. Donor concern about OH's mission calls into the question the long-term fundability of food-oriented CSOs like $\mathrm{OH}$. In addition, government funding is often late, inconsistent, or directed toward newer CSOs. This has only led to a spreading of fewer resources to more organizations. Also, while $\mathrm{OH}$ has used managerial ingenuity to partner with other relevant CSOs, OH's problems have sometimes been compounded by its weak institutional partners. Clearly, OH's future is very uncertain. 


\section{Discussion and conclusion}

This paper has analyzed the viability of South African CSOs through the lens of $\mathrm{OH}$. In theory, the state promotes policies which institutionalize, legitimize, and fund CSOs, private sector funds CSOs, and CSOs complement state programs and monitor the state to ensure accountability (Swilling, Russell, and Habib 2002). However, the experiences of $\mathrm{OH}$ suggest that these dynamics have only been partially realized. $\mathrm{OH}$ is now on the brink of closure, due to lack of long-term donor support for welfare programs or human capital, ineffective state funding, and competition from state programs and new CSOs. Although some of these problems may be specific to $\mathrm{OH}$, data in this paper support claims from other studies which indicate that lack of resources and weak or antagonistic relationships with partner organizations result in institutional instability among CSOs (Swilling, Russell, and Habib 2002), inadequate CSO service delivery (Warshawsky 2014), and ineffectual social movements (Ballard et al. 2006). If $\mathrm{OH}$, an organization with a long-standing in South Africa, closes, the prospects for other CSOs with similar historical backgrounds and circumstances may be uncertain.

As noted by scholars, CSOs maximize their autonomy by keeping a low profile, selective collaborations, increasing membership fees, and growing private fundraising (Bratton 1989; Salamon 1999; Smith 2012). However, as noted through the case study of $\mathrm{OH}$, this is not easily achieved, as $\mathrm{OH}$ has found its autonomy limited by its low or misunderstood profile due to the fraud crisis from the 1990s and its representation as a "welfare" organization. In addition, the success of its institutional collaborations has been mixed as its funders and partner NGOs have not always come through with results. Also, while $\mathrm{OH}$ is reluctant to implement membership fees due to the fragility of its partners, $\mathrm{OH}$ has pursued private fundraising and corporate partnerships. However, without human resources or time to network or market their organization, $\mathrm{OH}$ has been unable to access significant private resources. Although scholars have highlighted the risks of CSO commercialization as mission is often compromised at the expense of institutional self-perpetuation (Grønbjerg and Salamon 2012; Salamon 1993, 2012; Young, Salamon, and Grinsfelder 2012), administrators at $\mathrm{OH}$ are keen to remarket their organization to ensure its financial sustainability. In this way, self-perpetuation concerns are viewed as secondary to financial sustainability.

Most importantly, CSO autonomy is often limited by the state, private sector, and other CSOs. Foremost, this includes state control through monitoring, organization cooptation, and state penetration as the state actively seeks to 
control potentially adversarial or competitive CSOs (Bond 2006; Bratton 1989; Wolch 1990). In the case of $\mathrm{OH}$, government decisions not to fund $\mathrm{OH}$ projects, identify $\mathrm{OH}$ programs as in competition with state programs, fund "development" oriented CSOs or new CSOs only, and not provide promised funding, have collectively hurt $\mathrm{OH}$. In addition, corporations have the potential to influence the mission or stability of CSOs (Bond 2008). As noted in this paper, private donors have influenced OH's mission to become more developmental in order to receive funding; yet, they continue to mandate that money be spent on certain programs or for shorter time periods than needed. Lastly, competition from new CSOs has increased competition for funding (Mohan 2002), as state and private funders have chosen to fund newer upstart CSOs over long-standing CSOs like $\mathrm{OH}$.

In all, these trends point to broader challenges for South African CSOs. While some CSOs in South Africa have developed creative ways to access funding as noted above, it is uncertain whether funding streams are consistent or sufficient to sustain CSOs. Building on the work of Bond (2006) and Habib and Kotzé (2003), I argue that CSOs' polarization and institutional instability is not simply the result of restricted CSO autonomy (Swilling 2002). Rather, the struggles of South African CSOs, such as $\mathrm{OH}$, reflect CSOs' financial and political dependencies on the state and private sector.

Using the influential heuristic developed by Young (2000, 2006), South African CSOs can be understood as either adversarial (in opposition), supplementary (in addition), or complementary (in cooperation) to the state. In South Africa, adversarial CSOs played a key role in destroying apartheid and have continued to actively pressure the state, with no sign of diminishing (Ballard et al. 2006; Desai 2002). Supplementary and complementary CSOs have always been part of the South African social fabric, with the growth of complementary CSOs notable in the post-apartheid years as the state has funded many CSOs (Swilling et al. 2004). Importantly though, OH's struggles may be indicative of a weakening supplementary CSO sector, as the central state has actively funded certain complementary CSOs at the expense of some supplemental CSOs. This has been compounded by private donors' move away from many South African supplemental CSOs and increased competition from the growing number of supplemental CSOs. Overall, this suggests that South African democratization may have simultaneously produced new opportunities for some CSOs, yet reinforced unequal power relations for other CSOs and thus produced a highly polarized CSO landscape.

To maximize OH's viability, $\mathrm{OH}$ should hire skilled staff to pursue funding and development opportunities, institutional partnerships, and marketing promotions in different sectors both domestically and abroad. Domestic and 
international donors can also enable the success of CSOs like $\mathrm{OH}$ by reducing limits on administrative spending, allow more time to implement projects, and recognize the value in food-oriented CSOs like $\mathrm{OH}$. Most importantly, the South African state should increase funding to more CSOs, embrace CSOs which supplement government programs, and pay CSOs on time. While one should not exaggerate the potential of CSOs to effect social change or achieve development goals (Born and Purcell 2006; Mohan and Stokke 2000) and must not romanticize CSOs as post-political institutions (Bebbington, Hickey, and Mitlin 2008; Ferguson 2006), CSOs like $\mathrm{OH}$ make significant impacts when they operate at their maximum effectiveness.

While $\mathrm{OH}$ may operate for a few more years, it is unlikely that $\mathrm{OH}$ will persist for multiple decades unless it can secure long-term funding. If CSOs like $\mathrm{OH}$ close their operations, pressure on the state may intensify to fill these gaps. To some extent, this has already been seen as social protest and political instability have increased in the lead up to the 2014 general elections (Hart 2014). In addition, although the South African state spends 14\% of GDP or R118 billion yearly on welfare (South Africa National Treasury 2009), one of the highest rates in the Global South (World Bank 2008), pressure on the state to increase social welfare spending continues to persist (Desai, Maharaj, and Bond 2011). It is unclear that these expectations can be met in the coming decade, as poverty and social inequality endure (Desai, Maharaj, and Bond 2011; Hart 2014)

To examine whether $\mathrm{OH}$ reflects the experiences of other CSOs, future studies should analyze the web of institutional relationships which shape how CSOs operate in particular contexts. While some CSOs prosper due to their connections to global flows of information, money, and support (Bond 2008; Warshawsky 2011), other CSOs lack the capacity or knowledge to strengthen their institutions or serve their communities (Swilling, Russell, and Habib 2002; Warshawsky 2014). Importantly, future research could highlight the institutional choices available to CSOs in different socio-political contexts.

\section{References}

Ballard, R., A. Habib, I. Valodia, and E. Zuern. 2006. "Introduction: From Anti-Apartheid to PostApartheid Social Movements." In Voices of Protest, edited by R. Ballard, A. Habib, and I. Valodia, 1-22. Pietermaritzburg, South Africa: University of KwaZulu-Natal Press.

Barnard, D. 2013. "What You Need to Know." NGO Pulse. January 23, 2013. Accessed March 20, 2013. http://www.ngopulse.org/blogs/de-registration-npos-south-africa-what-you-needknow 
Bebbington, A. J., S. Hickey, and D. C. Mitlin. 2008. "Introduction: Can NGOs Make a Difference? The Challenges of Development Alternatives." In Can NGOs Make a Difference? edited by

A. J. Bebbington, S. Hickey, and D. C. Mitlin, 3-37. New York: Zed Books.

Bok, M. 2012. "Policy Brief on the Amendments of the Npo Act." NGO Pulse. September 27, 2012. Accessed March 19, 2013. http://www.ngopulse.org/article/policy-brief-amendments-npo-act

Bond, P. 2000. Elite Transition. Sterling, VA: Pluto Press.

Bond, P. 2006. "Johannesburg's Resurgent Social Movements.” In Challenging Hegemony, edited by N.C. Gibson, 103-28. Trenton, NJ: Africa World Press.

Bond, P. 2008. "Social Movements and Corporate Social Responsibility in South Africa." Development and Change 39:1037-52.

Born, B., and M. Purcell. 2006. "Avoiding the Local Trap: Scale and Food systems in Planning Research." Journal of Planning Education and Research 26:195-207.

Bratton, M. 1989. "The Politics of Government-NGO Relations in Africa." World Development 17:569-87.

Camay, P., and A. J. Gordon. 2001. Two Commas and a Full Stop. Civil Society Paper Series 1:1-53.

Department of Finance, Republic of South Africa. 1996. Growth, Employment, and Redistribution (GEAR). Accessed March 1, 2013. http://www.info.gov.za/otherdocs/ 1996/gear.pdf

Department of Provincial and Local Government (DPLG). 2000. A Policy Paper on Integrated Development Planning. Accessed March 1, 2013. http://www.thedplg.gov.za/index.php? option=com_docman\&task=doc_view\&gid=38

Department of Social Development, South Africa. 2012a. Policy Framework on Nonprofit Organisations Law: Proposed Amendments to the Nonprofit Organisations Act, Act 71 of 1997. Version 3. Accessed March 26, 2103. http://www.icnl.org/research/library/files/ South\%20Africa/policy-framework-npo-law.pdf

Department of Social Development, South Africa. 2012b. State of South African Registered Non-Profit Organisations Issued in Terms of the Non-Profit Organizations Act 71 of 1997. June 2012 version. Accessed March 26, 2013. http://www.dsd.gov.za/npo/index.php? option=com_docman\&task=cat_view\&ltemid $=39 \&$ gid $=81 \&$ orderby $=$ dmdate_published

Desai, A. 2002. We Are the Poors. New York: Monthly Review Press.

Desai, A., B. Maharaj, and P. Bond. 2011. "Introduction: Poverty Eradication as the Holy Grail."In Zuma's Own Goal: Losing South Africa's “War on Poverty”, edited by B. Maharaj, A. Desai, and P. Bond, 1-35. Trenton, NJ: Africa World Press.

Ferguson, J. 2006. Global Shadows: Africa in the Neoliberal World Order. Durham, NC: Duke University Press Books.

Friedman, S., J. Hudson, and S. Mackay. 2008. "New Whims for Old? Corporate Giving in South Africa." In Giving and solidarity, edited by A. Habib and B. Maharaj, 159-205. Cape Town: Human Sciences Research Council.

Greenstein, R., V. Heinrich, and K. Naidoo. 1998. The State of Civil Society in South Africa: Past Legacies, Present Realities, and Future Prospects. Johannesburg: Community Agency for Social Enquiry.

Habib, A. 2005. "State-Society Relations in Post-Apartheid South Africa." Social Research 72:671-93.

Habib, A. and H. Kotzé. 2003. "Civil Society, Governance and Development in an Era of Globalisation: The South African Case." In Governance in the New South Africa: The 
Challenges of Globalization, edited by G. Mhone and O. Edigheji, 246-270. Cape Town: University of Cape Town Press.

Habib, A., and R. Taylor. 1999. "South Africa: Anti-Apartheid NGOs in Transition." Voluntas 10:73-82.

Hart, G. 2014. Rethinking the South African Crisis: Nationalism, Populism, Hegemony. Pietermaritzburg, South Africa and Athens, GA: University of KwaZulu-Natal Press and University of Georgia Press.

Lewis, D. 2001. Management of Non-Governmental Development Organizations: An Introduction. New York: Routledge.

Miles, M. B., and A. M. Huberman. 1994. Qualitative Data Analysis. Thousand Oaks, CA: Sage. Mitchell, J. C. 1983. "Case and Situational Analysis Sociological Review 31:187-211.

Mohan, G. 2002. "The Disappointments of Civil Society: The Politics of NGO Intervention in Northern Ghana." Political Geography 21:125-54.

Mohan, G., and K. Stokke. 2000. "Participatory Development and Empowerment: The Dangers of Localism." Third World Quarterly 21:247-68.

Operation Hunger. 1996. Institutional Review. Operation Hunger: Germiston, South Africa. Operation Hunger. 2005. Annual Report. Operation Hunger: Germiston, South Africa. Operation Hunger. 2006. Annual Report. Operation Hunger: Germiston, South Africa. Operation Hunger. 2007. Annual Report. Operation Hunger: Germiston, South Africa. Operation Hunger. 2008. Annual Report. Operation Hunger: Germiston, South Africa. Operation Hunger. 2009. Annual Report. Operation Hunger: Germiston, South Africa. Operation Hunger. 2010. Annual Report. Operation Hunger: Germiston, South Africa. Operation Hunger. 2011. Annual Report. Operation Hunger: Germiston, South Africa. Operation Hunger. 2012. Annual Report. Operation Hunger: Germiston, South Africa.

Operation Hunger. 2013a. Operation Hunger Vision and Mission Statements. Germiston, South Africa. Accessed on March 26, 2013. http://www.operationhunger.co.za/pages/missionstatement.htm

Operation Hunger. 2013b. Summary of Projects per Region with Beneficiaries. Operation Hunger: Germiston, South Africa.

Pieterse, E., S. Parnell, M. Swilling, and M. van Donk. 2008. "Consolidating Developmental Local Government." In Consolidating Developmental Local Government, edited by M. van Donk, M. Swilling, E. Pieterse, and S. Parnell, 1-23. Cape Town: University of Cape Town Press.

Republic of South Africa. 1997a. Lotteries Act of 1997. Accessed March 26, 2013. http://www. info.gov.za/view/DownloadFileAction?id=70803

Republic of South Africa. 1997b. Nonprofit Organisations Act. Accessed March 26, 2103. http:// www.info.gov.za/view/DownloadFileAction?id=70816

Republic of South Africa. 1998a. National Development Agency Act of 1998. Accessed March 26, 2013. http://www.info.gov.za/view/DownloadFileAction?id=71592

Republic of South Africa. 1998b. White Paper on Local Government. Accessed March 26, 2013. www.info.gov.za/view/DownloadFileAction?id=108131

Rogerson, C. M. 2004. "Ten Years of Changing Development Planning in a Democratic South Africa." International Development Planning Review 26:355-58.

Salamon, L. M. 1993. "The Marketization of Welfare: Changing Nonprofit and For-Profit Roles in the American Welfare State." Social Services Review 67:16-37.

Salamon, L. M. 1999. "The Nonprofit Sector at a Crossroads: The Case of America." Voluntas: International Journal of Voluntary and Nonprofit Organizations 10:5-23. 
Salamon, L. M. 2010 "Putting the Civil Society Sector on the Economic Map of the World." Annals of Public and Cooperative Economics 81:167-210.

Salamon, L. M. 2012. "The Resilient Sector: The Future of Nonprofit America." In The State of Nonprofit America, edited by L. M. Salamon, 3-86. Washington, DC: Brookings Institution Press.

Salamon, L. M., S. W. Sokolowski, and R. List. Associates. 2004. In Global Civil Society: Volume Two, edited by L. M. Salamon, S. W. Sokolowski, and Associates, 3-60. Bloomfield, CT: Kumarian Press.

Sayer, A. 1992. "Problems of Explanation and the Aims of Social Science." In Method in Social Science, edited by A. Sayer, 232-57. London and New York: Routledge.

Smith, S. R. 2012. "Social Services." In The State of Nonprofit America, 2nd ed., edited by L. M. Salamon, 192-228. Washington, DC: Brookings Institution Press.

South Africa National Treasury. 2009. Budget Highlights. Pretoria. Accessed October, 202010. http://www.treasury.gov.za/documents/national\%20budget/2009/guides/Treasury\% 20budget\%20highlights.pdf

Swilling, M. 2002. Implications of the South African Non-Profit Sector Study. Stellenbosch: University of Stellenbosch.

Swilling, M., B. Russell, and A. Habib. 2002. The Size and Scope of the Non-Profit Sector in South Africa. Johannesburg: University of the Witwatersrand.

Swilling, M., B. Russell, S. W. Sokolowski, and L. M. Salamon. 2004. South Africa. In Global Civil Society: Volume Two, edited by L. M. Salamon, S. W. Sokolowski, and Associates, 110-25. Bloomfield, CT: Kumarian Press.

Terreblanche, S. 2002. A History of Inequality in South Africa. Pietermaritzburg, South Africa: University of Natal Press.

Tostensen, A., I. Tvedten, and M. Vaa. 2001. "The Urban Crisis, Governance and Associational Life." In Associational Life in African Cities: Popular Responses to the Urban Crisis, edited by A. Tostensen, I. Tvedten, and M. Vaa, 7-26. Uppsala, Sweden: Nordiska Afrikainstitutet

Umhlaba Development Services. 2005. An Impact Assessment of the NPO Act, No. 71 of 1997. Johannesburg: Umhlaba Development Services.

Warshawsky, D. N. 2011. "FoodBank Johannesburg, State, and Civil Society Organisations in Post-Apartheid Johannesburg." Journal of Southern African Studies 37:809-29.

Warshawsky, D. N. 2013. "Measuring the Size, Scope, and Location of Civil Society Organizations in Johannesburg's Food System." The Professional Geographer 65: 594-611.

Warshawsky, D. N. 2014. "Civil Society and Urban Food Insecurity: Analyzing the Roles of Local Food Organizations in Johannesburg." Urban Geography 35:109-32.

Wolch, J. R. 1990. The Shadow State. New York: The Foundation Center.

World Bank. 2008. Safety Net spending. Washington, DC. Accessed October 20, 2010. http:// siteresources.worldbank.org/SAFETYNETSANDTRANSFERS/Resources/SN_Expenditures_630-08.xls

Wyngaard, R. 2013. "The South African Npo Crisis: Time to Join Hands." NGO Pulse. March 12, 2013. Accessed March 29, 2013. http://www.ngopulse.org/article/south-african-npo-crisis-time-join-hands

Yeung, H. W. 1997. "Critical Realism and Realist Research in Human geography: A Method or a Philosophy in Search of a Method." Progress in Human Geography 21:51-74.

Yeung, H. W. 2003. "Practicing New Economic Geographies: A Methodological Examination." Annals of the Association of American Geographers 93:442-62. 
Young, D. R. 2000. "Alternative Models of Government-Nonprofit Sector Relations: Theoretical and International Perspectives." Nonprofit and Voluntary Sector Quarterly 29:149-72.

Young, D. R. 2006. "Complementary, Supplementary, or Adversarial? Nonprofit-Government Relations." In Nonprofits and Government, edited by E. T. Boris and C. E. Steuerle, 37-79. Washington, DC: The Urban Institute Press.

Young, D. R., Salamon, L. M., and M. C. Grinsfelder. 2012. “Commercialization, Social Ventures, and For-Profit Competition." In The State of Nonprofit America, 2nd ed., edited by L. M. Salamon, 521-48. Washington, DC: Brookings Institution Press. 